\title{
Sediment records of highly variable mercury inputs to mountain lakes in Patagonia during the past millennium
}

\author{
S. Ribeiro Guevara ${ }^{1}$, M. Meili ${ }^{2}$, A. Rizzo ${ }^{1,3}$, R. Daga ${ }^{1,3}$, and M. Arribére ${ }^{1,4}$ \\ ${ }^{1}$ Laboratorio de Análisis por Activación Neutrónica, Comisión Nacional de Energía Atómica, Centro Atómico Bariloche, \\ 8400 Bariloche, Argentina \\ ${ }^{2}$ Department of Applied Environmental Science, Stockholm University, 10691 Stockholm, Sweden \\ ${ }^{3}$ Consejo Nacional de Investigaciones Científicas y Técnicas, Rivadavia 1917, Ciudad de Buenos Aires, Argentina \\ ${ }^{4}$ Instituto Balseiro, Universidad Nacional de Cuyo, 8400 Bariloche, Argentina
}

Received: 15 September 2009 - Published in Atmos. Chem. Phys. Discuss.: 2 December 2009

Revised: 26 March 2010 - Accepted: 6 April 2010 - Published: 14 April 2010

\begin{abstract}
High Hg levels in the pristine lacustrine ecosystems of the Nahuel Huapi National Park, a protected zone situated in the Andes of Northern Patagonia, Argentina, have initiated further investigations on $\mathrm{Hg}$ cycling and source identification. Here we report $\mathrm{Hg}$ records in sedimentary sequences to identify atmospheric sources during the past millennium. In addition to global transport and deposition, a potential atmospheric Hg source to be considered is the local emissions associated with volcanic activity, because the Park is situated in the Southern Volcanic Zone. Two sediment cores were extracted from Lake Tonček, a small, highaltitude system reflecting mainly direct inputs associated with atmospheric contributions, and Lake Moreno Oeste, a much larger and deeper lake having an extended watershed covered mostly by native forest.

The sedimentary sequences were dated based on both ${ }^{210} \mathrm{~Pb}$ and ${ }^{137} \mathrm{Cs}$ profiles. In addition, tephra layers were identified and geochemically characterized for chronological application and to investigate any association of volcanic eruptions with $\mathrm{Hg}$ records. $\mathrm{Hg}$ concentrations in sediments were measured along with 32 other elements, as well as organic matter, subfossil chironomids, and biogenic silica. Observed background $\mathrm{Hg}$ concentrations, determined from the sequence domains with lower values, ranged from 50 to $100 \mathrm{ng} \mathrm{g}^{-1}$ dry weight (DW), whereas the surficial layers reached 200 to $500 \mathrm{ng} \mathrm{g}^{-1}$ DW. In addition to this traditional pattern, however, two deep domains in both sequences showed dramatically increased $\mathrm{Hg}$ levels reaching 400 to $650 \mathrm{ng} \mathrm{g}^{-1} \mathrm{DW}$; the upper dated to the 18 th to 19 th centuries,
\end{abstract}

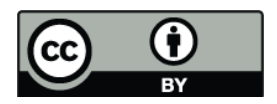

Correspondence to: S. Ribeiro Guevara (ribeiro@cab.cnea.gov.ar) and the lower around the 13th century. These concentrations are not only elevated in the present profiles but also many-fold above the background values determined in other fresh water sediments, as were also the $\mathrm{Hg}$ fluxes, reaching 120 to $150 \mu \mathrm{g} \mathrm{m}^{-2} \mathrm{y}^{-1}$ in Lake Tonček. No correlation was observed between $\mathrm{Hg}$ concentrations and the contents of organic matter, subfossil chironomids, biogenic silica, or the other elements determined. However, distinctly increased $\mathrm{Hg}$ concentrations were observed immediately above some tephra layers, suggesting a link to volcanic events. Extended fires might be another potential atmospheric source because the earlier $\mathrm{Hg}$ peaks coincide with reported charcoal peaks, whereas the upper $\mathrm{Hg}$ peaks coincide with evidences of extended forest fires from tree-ring data and historical records.

\section{Introduction}

Even though aquatic ecosystems are globally exposed to mercury $(\mathrm{Hg})$ by atmospheric inputs of increasing concern, few studies have been focusing on the sources, fate and history of freshwater systems of the southern hemisphere that are free from major contamination (Downs et al., 1998; Lamborg et al., 2002; Biester et al., 2007). Here, we used sediment profiles as historical archives to reveal changes in the $\mathrm{Hg}$ cycling in two lakes of the southern Andes over the past centuries. Although no relevant point source of $\mathrm{Hg}$ from mining or industrial activities has been identified in the study region, high $\mathrm{Hg}$ levels in various ecosystem compartments have been reported, notably in both native and introduced fish species, where levels ranged from 0.06 to $4 \mu \mathrm{g} \mathrm{g}^{-1}$ dry weight (DW) in liver, and from 0.07 to $2.5 \mu \mathrm{g} \mathrm{g}^{-1} \mathrm{DW}$ in

Published by Copernicus Publications on behalf of the European Geosciences Union. 
muscle (Arribére et al., 2008), whereas Hg concentrations in lichens and mussels, used as air and water bioindicators respectively, were compatible with those at locations exposed to moderate contamination (Ribeiro Guevara et al., 2004a; Ribeiro Guevara et al., 2004b), suggesting that the anomaly is not limited to aquatic systems.

The western part of the Park receives high precipitation, reaching $3000 \mathrm{~mm} \mathrm{y}^{-1}$. Therefore, global transport and wet deposition, a well-known $\mathrm{Hg}$ source to aquatic environments (Downs et al., 1998), should be considered to contribute to the $\mathrm{Hg}$ burden in the study region. But other $\mathrm{Hg}$ sources have to be taken into account. Forest fires, volcanoes and geothermal vents, and Hg-enriched soils have been recognized as natural $\mathrm{Hg}$ sources to the atmosphere (Nriagu, 1989; Lindqvist et al., 1991; Schroeder and Munthe, 1998; Wiedinmyer and Friedly, 2007). Geological sources are associated with plate tectonic boundaries (Varenkamp and Brusek, 1984; Rasmussen, 1994), including areas of geothermal and volcanic activity, which are considered as the foremost natural source of $\mathrm{Hg}$ (Nakagawa, 1999; Ferrara et al., 2000; Tomiyasu et al., 2000). Cataclysmic volcanoes have the potential to inject enough volatile $\mathrm{Hg}$ into the stratosphere to change the global and regional cycle of $\mathrm{Hg}$ for a few years, while quiescent degassing and moderate eruptions exhale directly into the troposphere and can also have long-term effects on the local environments (Langway et al., 1995). Geothermal activity has been associated with high $\mathrm{Hg}$ levels in soils and air at several places (Siegel and Siegel, 1975; Weissberg and Rohde, 1978; Varenkamp and Buseck, 1986). Volcanogenic $\mathrm{Hg}$ can readily enter the aquatic food chain after being released, enlarging bio-available stocks (Nriagu and Becker, 2003). Volcanic activity is a potential source to be considered in the present work because the lakes under study are within the Southern Volcanic Zone (SVZ) (Stern, 2004), including several volcanoes active during the Holocene. Forest fires can drastically reduce the pool of $\mathrm{Hg}$ in catchment soils and release biomass inventories because of volatilization of elemental $\mathrm{Hg}$ to the atmosphere (Friedli et al., 2003; Sigler et al., 2003; Amirbahman et al., 2004, Harden et al., 2004), potentially enlarging sediment $\mathrm{Hg}$ burden by transport and wet or dry deposition. Up to 6 fold increase in $\mathrm{Hg}$ concentrations in sediments of Caballo Reservoir, New Mexico, USA, was observed after a forest fire and storm runoff, suggesting that the combination of both phenomena enhanced the transport of $\mathrm{Hg}$ from the watershed to the water body (Caldwell et al., 2000), and might contribute to increasing $\mathrm{Hg}$ contents in sediments after fires. Kelly et al. (2006) observed a large short-term pulse of $\mathrm{Hg}$ mobilized by post-fire runoff in Lake Moab, Jasper National Park, Canada.

In an earlier screening research on lake sedimentary sequences in the study region (Ribeiro Guevara et al., 2005), upper layers, associated with 20th century accumulation periods, showed in most cases concentrations elevated above background levels, reaching values as high as 1 to $3 \mu \mathrm{g} \mathrm{g}^{-1}$ DW. However, Hg concentrations 3 to 5-fold above back- ground levels ( 0.1 to $0.2 \mu \mathrm{g} \mathrm{g}^{-1} \mathrm{DW}$ ) were observed in deep layers, focusing hence our attention on natural inputs during the past millennium, and driving present work. Here, two dated sedimentary sequences were studied with a more sensitive technique for $\mathrm{Hg}$ determinations (Instrumental Neutron Activation Analysis was used in previous works), and with additional methods to analyze other selected elements and environmental tracers.

\section{Experimental}

\subsection{Study site}

The Nahuel Huapi National Park is situated in Northern Patagonia, on the eastern slope of the southern Andes $\left(40^{\circ} 20^{\prime}\right.$ to $41^{\circ} 40^{\prime} \mathrm{S}, 71^{\circ}$ to $72^{\circ} \mathrm{W}$; Fig. 1) and is the largest protected natural area of Argentina, covering approximately $7100 \mathrm{~km}^{2}$ and comprising a drainage basin that includes three major river systems, thirteen lakes of more than $10 \mathrm{~km}^{2}$, and several hundred small lakes and ponds. Within the Park's limits there are pristine as well as moderately impacted areas, such as the city and suburbs of San Carlos de Bariloche, with a population of circa 120000 people. Its economy, as well as that of other small towns and villages in the Park, is largely based on tourism.

The Park is located in the Northern Patagonian Andes $\left(39^{\circ}\right.$ to $\left.45^{\circ} \mathrm{S}\right)$, a region that is part of the Southern Volcanic Zone (SVZ). The SVZ includes at least 60 historically and potentially active volcanic edifices in Chile and Argentina, three giant silicic caldera systems and numerous minor eruptive centers (Stern, 2004). The Northern Patagonian segments of the volcanic arc include several centers which are active since the Miocene to present (Villarrica, Nilahue, Puyehue-Cordón Caulle, Cerro Puntiagudo, Osorno, and Calbuco, among others), with several events registered in historical records since the Spanish colonisation (Ramos, 1999; Stern, 2004). An analysis of volcanic ash records in short lacustrine sedimentary sequences from this region showed up to 9 tephra layers deposited in the past 1000 years (Daga et al., 2008).

Two sedimentary sequences were extracted from Lake Moreno Oeste and Lake Tonček (Fig. 1). Lake Moreno Oeste is the western branch of Lake Moreno $\left(41^{\circ} 5^{\prime} \mathrm{S} ; 71^{\circ} 33^{\prime} \mathrm{W}\right.$, $758 \mathrm{~m}$ above sea level), draining into Lake Nahuel Huapi. Lake Moreno Oeste has a surface area of $6 \mathrm{~km}^{2}$ and a maximum depth of $90 \mathrm{~m}$, and is an ultraoligotrophic, warm monomictic system stratified from late spring to early autumn (Queimaliños et al., 1999; Díaz et al., 2007). The lake is surrounded mostly by closed native forest dominated by Nothofagus dombeyi and lesser amounts of Austrocedrus chilensis. This environment has persisted, with variations in the relative composition, during the last millennium (Whitlock et al., 2006). The sampling point is located at Llao Llao 


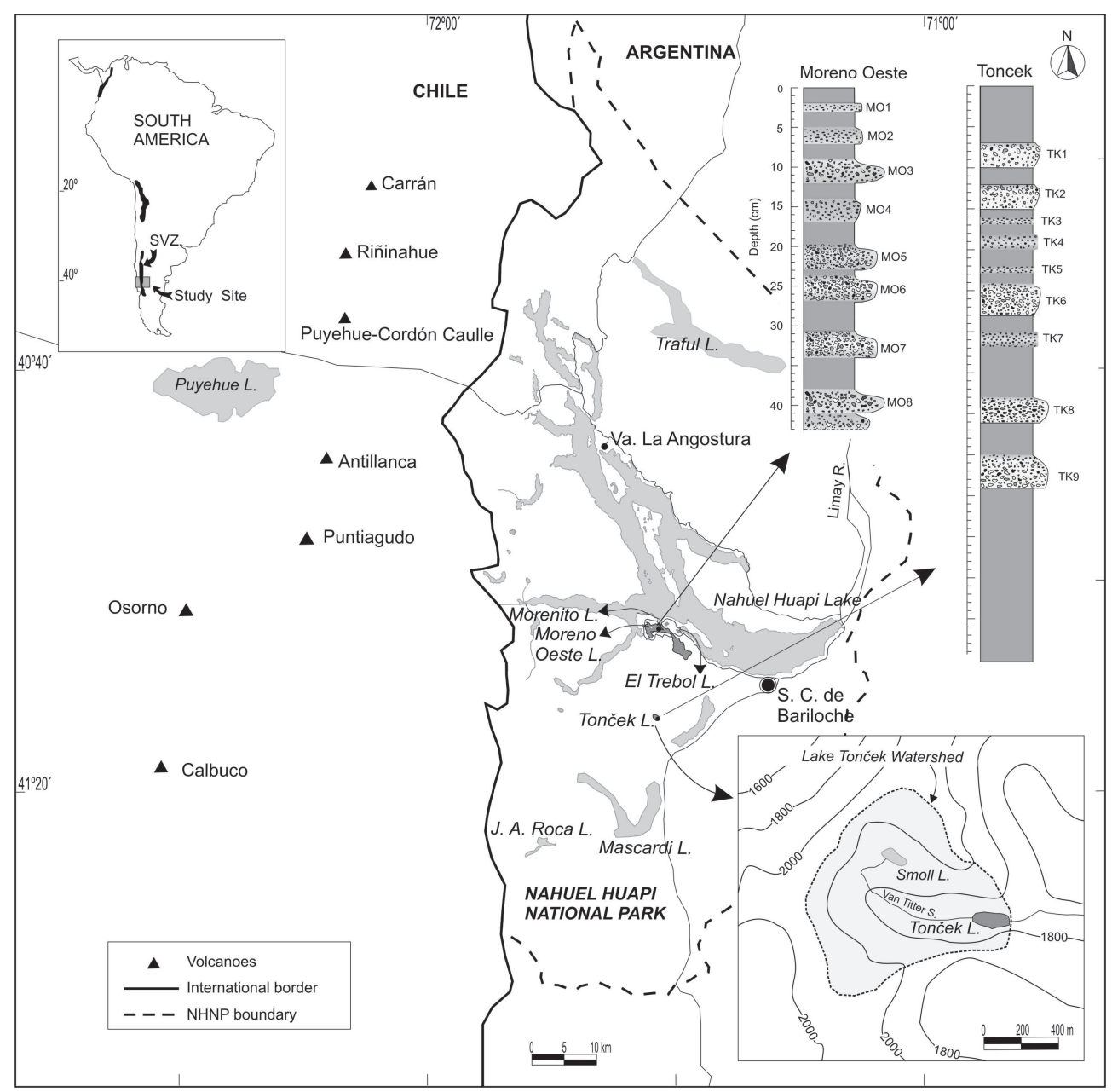

Fig. 1. Study area. Section of Nahuel Huapi National Park, Northern Patagonia, Argentina.

bay, a sub-basin with a rather flat bottom at $20 \mathrm{~m}$ depth, without tributaries.

Lake Tonček $\left(41^{\circ} 12^{\prime} \mathrm{S} ; 71^{\circ} 29^{\prime} \mathrm{W}, 1750 \mathrm{~m}\right.$ above sea level) is a small lake with $0.03 \mathrm{~km}^{2}$ surface area and $12 \mathrm{~m}$ maximum depth, of glacial origin, situated in Catedral mountain approximately $16 \mathrm{~km}$ to the south of Lake Moreno Oeste, at the foot of high peaks with steep slopes. It is an ultraoligotrophic, dimictic system, with direct stratification in summer and 6 to 8 months of ice cover reaching a thickness of up to $2 \mathrm{~m}$. Lake Tonček watershed is small, with an extension of approximately $2.5 \mathrm{~km}^{2}$ including one smaller lake situated about $100 \mathrm{~m}$ higher, which is connected to Lake Tonček by a small inlet stream meandering across wetlands. Reddish coloration and sulphydric smell in these wetlands have been reported at the end of the summer, when eutrophication processes are developed, potentially impacting $\mathrm{Hg}$ cycling in the water body. The lake has two distinct sections: a deep central zone that is surrounded like a ring by a shallow outer zone which is $0.5 \mathrm{~m}$ deep and up to $30 \mathrm{~m}$ wide. The boundary between the two sections is a steep slope dropping to $12 \mathrm{~m}$. Lake Tonček watershed is dominated by rocky ground deposits, and scattered timberline forest (Nothofagus pumilio "krummholz") and high-Andean vegetation (Gaultheria pumila and Baccharis magellanica). The water body encloses a simple trophic structure without fish, and the community structure of zooplankton is relatively simple (Morris et al., 1995; Marinone et al., 2006).

\subsection{Methods}

Short sediment cores were extracted with a messengeractivated gravity corer from the deepest part of the lakes Moreno Oeste (Llao Llao bay) and Tonček (Fig. 1). Core lengths were 43 and $70 \mathrm{~cm}$ for Lake Moreno Oeste, and Lake Tonček, respectively. The sediment cores were cut opened longitudinally using a portable circular saw to section the tube walls, sliding afterwards a copper plate through the sediment to divide it into two semi-cylindrical sections. Both sections were sub-sampled every $1 \mathrm{~cm}$. Each sub-sampled sediment layer was freeze-dried until constant weight and homogenised. Tephra layers were identified visually in the 
sedimentary sequence before sub-sampling, whereas they were analyzed under binocular magnifying glass after freezedrying.

The sediment accumulation rates of the sediment sequences were determined by ${ }^{210} \mathrm{~Pb}$ and ${ }^{137} \mathrm{Cs}$ dating techniques (Joshi and Shukla, 1991; Robbins and Herche, 1993; Ribeiro Guevara and Arribére, 2002). ${ }^{210} \mathrm{~Pb},{ }^{226} \mathrm{Ra}$ (in secular equilibrium with supported ${ }^{210} \mathrm{~Pb}$ ), and ${ }^{137} \mathrm{Cs}$ specific activity was measured in each layer by high-resolution gamma spectrometry. The Constant Rate of Supply model was used for ${ }^{210} \mathrm{~Pb}$ dating. Correction of the old-date error of the model was implemented by logarithmic extrapolation to infinite depth (Ribeiro Guevara et al., 2003). For ${ }^{137}$ Cs dating, the specific activity profiles were compared with the fallout sequence determined in this region, associated mainly with South Pacific nuclear tests from 1966 to 1974 (Ribeiro Guevara and Arribére, 2002). The dates for the events registered in the sedimentary sequences before 1900 were obtained by extrapolation of the sedimentation rate determined in the upper layers. The extrapolation was computed in depth units of cumulative mass per surface unit, discounting volcanic ashes from bulk sediments by estimating the fraction in each layer from the analysis under binocular microscope.

The organic matter content $(\mathrm{OM})$ of the freeze-dried sediments was estimated as loss on ignition (LOI) at $550^{\circ} \mathrm{C}$ for $4 \mathrm{~h}$.

Total $\mathrm{Hg}$ was analyzed by atomic absorption spectrometry directly after high-temperature combustion and catalytic reduction using a Milestone Direct Mercury Analyser (DMA 80, Milestone Inc., Monroe, CT, USA, http://www.milestonesci.com/mercury-dma.php) according to the US-EPA Method 7473 (US-EPA, 2007), and following the quality assurance routines of the laboratory at ITM as specified under Swedish Accreditation (SWEDAC Nr. 1295, Swedish Board for Technical Assistance, http://www. swedac.se). Samples were frequently replicated (up to fourfold), and blanks and certified standard reference materials (here GBW07405/NCS DC 73323) were analyzed daily to assure adequate performance and accuracy. Detection limit (3 SD of blanks) for the applied procedure was $<3 \mathrm{ng} \mathrm{g}^{-1}$ DW. Precision ( $1 \mathrm{RSD}$ at $>100 \mathrm{ng} \mathrm{g}^{-1} \mathrm{DW}$ ) was $2 \%$ in homogenous reference samples and $4 \%$ in actual samples. Total $\mathrm{Hg}$ was determined in bulk sediment except for tephra layers, where the $<63 \mu \mathrm{m}$ fraction was analyzed.

The elemental composition of the sediment samples was determined by Instrumental Neutron Activation Analysis, as described by Daga et al. (2008). The elements measured were major elements including $\mathrm{Al}, \mathrm{Ca}, \mathrm{Fe}, \mathrm{Mg}, \mathrm{Mn}, \mathrm{Na}, \mathrm{K}$, and $\mathrm{Ti}$, rare earths elements $\mathrm{La}, \mathrm{Ce}, \mathrm{Nd}, \mathrm{Sm}, \mathrm{Eu}, \mathrm{Tb}, \mathrm{Tm}$, $\mathrm{Yb}, \mathrm{Lu}$, and other relevant trace elements including $\mathrm{Sb}, \mathrm{As}$, $\mathrm{Ba}, \mathrm{Br}, \mathrm{Cs}, \mathrm{Zn}, \mathrm{Co}, \mathrm{Cr}, \mathrm{Hf}, \mathrm{Sc}, \mathrm{Sr}, \mathrm{Ta}, \mathrm{Th}, \mathrm{U}$, and V. The elements selected are biological and geological tracer that could provide information on environmental changes.

Records of subfossil chironomid assemblages were studied in Lake Tonček sediments by picking up head capsules from the sediment according to standard methods (Walker, 2001). The chironomid head capsules were mounted on microscope slides and identified using current taxonomic guides, determining the relative abundance profile of each taxon.

Biogenic silica (BSi) concentration was measured in Lake Tonček sediments using the method outlined by DeMaster (1981). Sediment samples that weighed about $20 \mathrm{mg}$ were leached in $1 \% \mathrm{Na}_{2} \mathrm{CO}_{3}$ over time, and aliquots were analyzed for BSi concentrations using the reduced molybdosilicate acid colorimetric method. Weight percent of total silica was plotted versus time and the extrapolated intercept was used to calculate the BSi concentration of the sediment.

\section{Results}

\subsection{Sediment sequences dating}

A sediment accumulation rate of $13.3 \mathrm{mg} \mathrm{cm}^{-2} \mathrm{y}^{-1}$ $\left(0.058 \mathrm{~cm} \mathrm{y}^{-1}\right)$ and a ${ }^{210} \mathrm{~Pb}$ flux of $23.7 \mathrm{~Bq} \mathrm{~m}^{-2} \mathrm{y}^{-1}$ were determined in the upper $5 \mathrm{~cm}$ of the Lake Moreno Oeste sequence (Daga et al., 2008), whereas a sediment accumulation rate of $26.3 \mathrm{mg} \mathrm{cm}^{-2} \mathrm{y}^{-1}\left(0.105 \mathrm{~cm} \mathrm{y}^{-1}\right)$ and a ${ }^{210} \mathrm{~Pb}$ flux of $74.2 \mathrm{~Bq} \mathrm{~m}^{-2} \mathrm{y}^{-1}$ were obtained for the upper $7 \mathrm{~cm}$ of Lake Tonček. Tephra layers are evidenced in the ${ }^{210} \mathrm{~Pb}$ profile as depressed or even negligible activities of unsupported ${ }^{210} \mathrm{~Pb}$ (total ${ }^{210} \mathrm{~Pb}$ minus supported ${ }^{210} \mathrm{~Pb}$, in secular equilibrium with ${ }^{226} \mathrm{Ra}$ ). Such a decrease of unsupported ${ }^{210} \mathrm{~Pb}$ is observed in the $0.4-0.7 \mathrm{~g} \mathrm{~cm}^{-2}$ layer of the Lake Moreno Oeste sequence (Fig. 2), corresponding to the 1948-1970 deposition period, and in the $1.0-1.3 \mathrm{~g} \mathrm{~cm}^{-2}$ layer of the Lake Tonček sequence (Fig. 3), corresponding to the 19531964 deposition period. This decrease is compatible with the Puyehue-Cordón Caulle and Calbuco volcanic events in 1960-1961 (Daga et al., 2008) causing bulk sediment dilution by volcanic ashes, which were also identified under binocular magnifying glass. Unsupported ${ }^{210} \mathrm{~Pb}$ values in these layers were corrected before dating. It is necessary to emphasize that the dating before 1900 , which is based on the assumption that there was no persistent change in sedimentation rate, is somewhat uncertain particularly for early events. An independent dating corroboration was obtained in the Lake Moreno Oeste sequence. The tephra layer MO5 (Fig. 4) could be associated with a volcanic event in 1759, in agreement with the ${ }^{210} \mathrm{~Pb}$ and ${ }^{137} \mathrm{Cs}$ dating extrapolation.

Interestingly, the ${ }^{210} \mathrm{~Pb}$ flux is three fold higher in Lake Tonček compared to Lake Moreno Oeste, and it is the highest measured in the region based on 10 sedimentary sequences studied in a previous work (Ribeiro Guevara et al., 2003). A positive correlation between ${ }^{210} \mathrm{~Pb}$ flux and the OM concentration of the upper layer of these lakes was reported (Ribeiro Guevara et al., 2003), however Lake Tonček ${ }^{210} \mathrm{~Pb}$ flux does not fit this correlation. The relative high ${ }^{210} \mathrm{~Pb}$ flux to Lake Tonček sediments is consistent with the assumption that due 


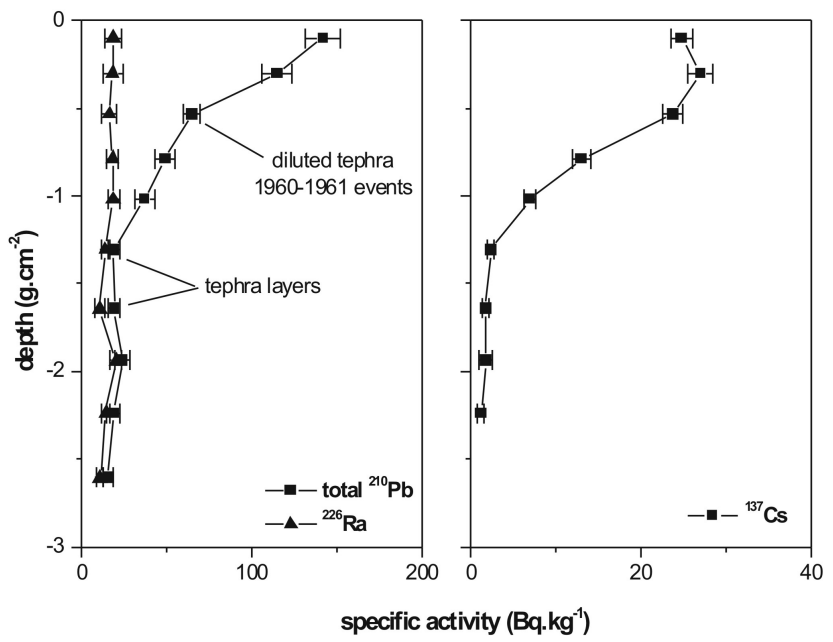

Fig. 2. Moreno Oeste sedimentary sequence. Specific activity profiles of ${ }^{137} \mathrm{Cs},{ }^{210} \mathrm{~Pb}$, and ${ }^{226} \mathrm{Ra}$ (in secular equilibrium with supported ${ }^{210} \mathrm{~Pb}$ ).

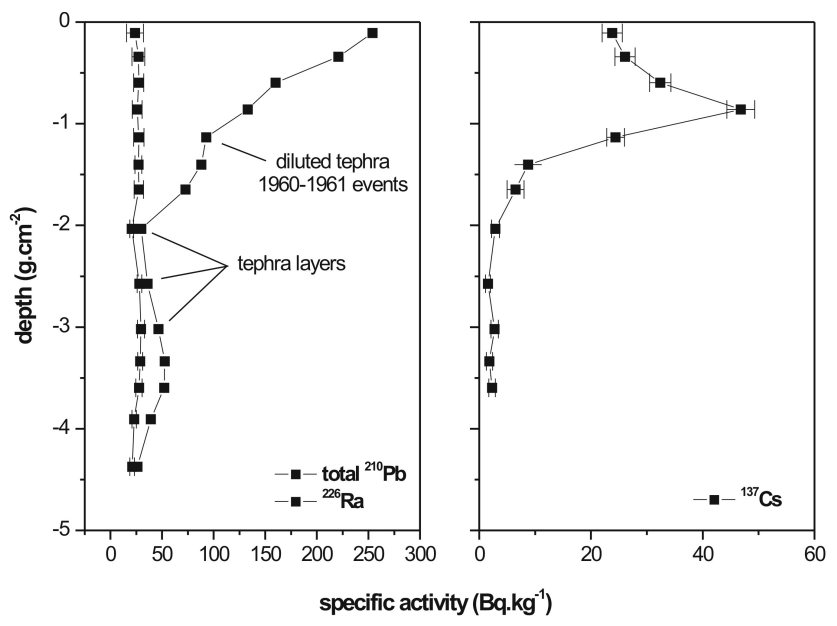

Fig. 3. Lake Tonček sedimentary sequence. Specific activity profiles of ${ }^{137} \mathrm{Cs},{ }^{210} \mathrm{~Pb}$, and ${ }^{226} \mathrm{Ra}$ (in secular equilibrium with supported ${ }^{210} \mathrm{~Pb}$ ).

to the characteristics of the catchment area, the sediments of this water body are a good recorder of atmospheric fallout, with relative low retention in the catchment area.

\subsection{Mercury}

The $\mathrm{Hg}$ concentration profiles of Lake Tonček and Lake Moreno Oeste, Llao Llao bay, sedimentary sequences are shown in Fig. 4, respectively. Hg fluxes to sediments (Fig. 5) were computed for each layer based on the core dating. The profiles of $\mathrm{Hg}$ concentration and $\mathrm{Hg}$ fluxes to the sediments of Lake Tonček sequence (Figs. 4 and 5) show five domains clearly demarcated. Low $\mathrm{Hg}$ levels were observed before 1200 and between 1350 and 1720, indicating background of 50 to $80 \mathrm{ng} \mathrm{g}^{-1}$ for concentration, and 15 to $25 \mu \mathrm{g} \mathrm{m}^{-2} \mathrm{y}^{-1}$

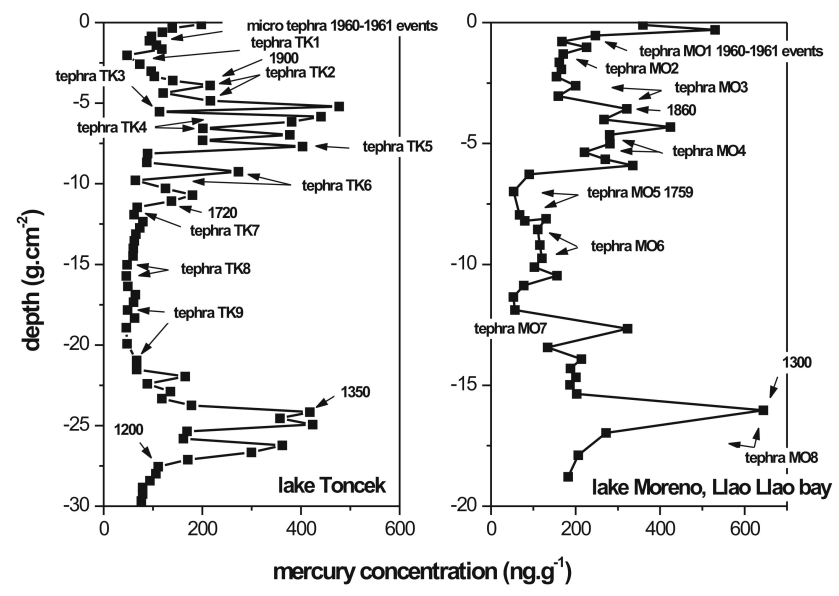

Fig. 4. Mercury concentration profiles. Lake Tonček and Lake Moreno Oeste (Llao Llao bay) sedimentary sequences.

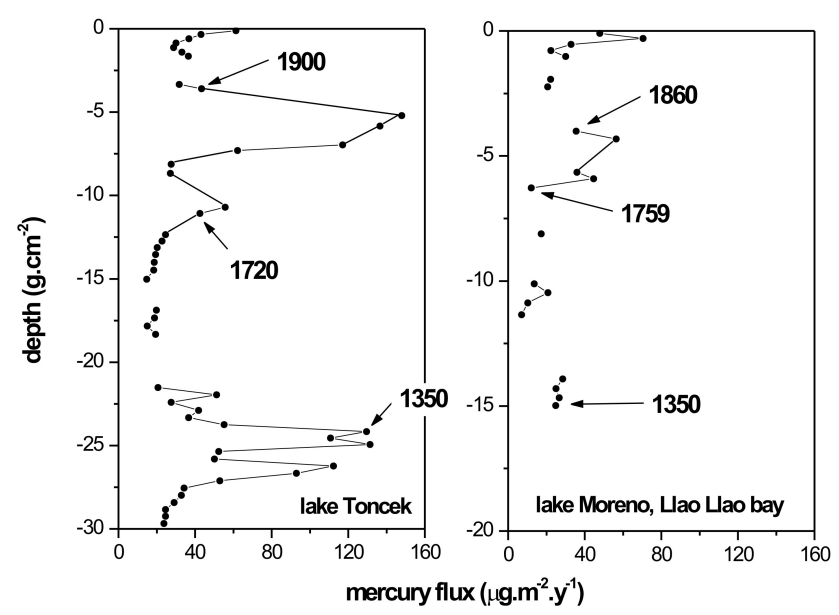

Fig. 5. Mercury fluxes to sediments. Lake Tonček and Lake Moreno Oeste (Llao Llao bay) sedimentary sequences.

for fluxes. In the upper core section, starting about 1900, Hg levels increase from low values (though above background) to reach a concentration of $200 \mathrm{ng} \mathrm{g}^{-1}$ and a $\mathrm{Hg}$ flux of $60 \mu \mathrm{g} \mathrm{m}^{-2} \mathrm{y}^{-1}$ at present. Two intermediate sections show $\mathrm{Hg}$ values noticeably elevated above background. From 1720 to $1900, \mathrm{Hg}$ level varied dramatically, with the high concentrations and fluxes reaching 380 to $480 \mathrm{ng} \mathrm{g}^{-1}$ and 140 to $150 \mu \mathrm{g} \mathrm{m}^{-2} \mathrm{y}^{-1}$, respectively. From 1200 to $1350, \mathrm{Hg}$ values show two marked peaks, which reach concentrations of 360 and $420 \mathrm{ng} \mathrm{g}^{-1}$ and fluxes of 110 and $130 \mu \mathrm{g} \mathrm{m}^{-2} \mathrm{y}^{-1}$, respectively. Lake Moreno Oeste $\mathrm{Hg}$ profiles (Figs. 4 and 5) exhibit a similar pattern as Lake Tonček, showing correlation in the occurrence of high $\mathrm{Hg}$. Background $\mathrm{Hg}$ concentrations and fluxes range from 50 to $80 \mathrm{ng} \mathrm{g}^{-1}$ and from 7 to $10 \mu \mathrm{g} \mathrm{m}^{-2} \mathrm{y}^{-1}$, respectively, while $\mathrm{Hg}$ peak concentrations and fluxes range from 300 to $650 \mathrm{ng} \mathrm{g}^{-1}$ and 35 to $55 \mu \mathrm{g} \mathrm{m}^{-2} \mathrm{y}^{-1}$, respectively. 


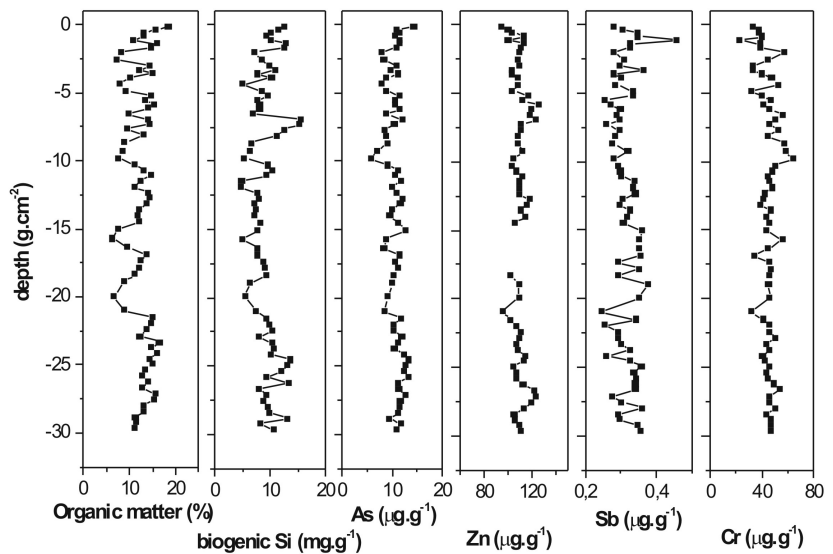

Fig. 6. Lake Tonček sedimentary sequence. Organic matter, biogenic $\mathrm{Si}$ and heavy metals concentration profiles.

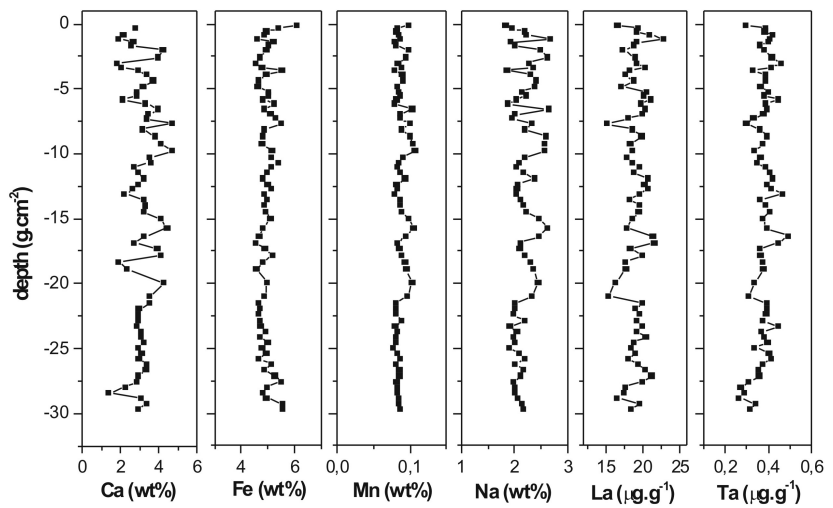

Fig. 7. Lake Tonček sedimentary sequence. Selected major elements and geochemical tracer concentration profiles.

\subsection{Environmental tracers}

The analysis of subfossil chironomids in the Lake Tonček sequence allowed the identification of twelve taxa corresponding to subfamilies Orthocladiinae, Tanypodinae, Podonominae and Chironominae (Tribu Chironomini). The dominant taxon of the chironomid community along the sequence was the cold-stenothermic Pseudosmittia Goetghebuer (Rizzo et al., 2007). The OM contents ranged from 6 to $18 \%$, with the highest value in the upper most layer and decreasing in the tephra layers (Fig. 6). The BSi concentration exhibited a similar trend, with the exception of two peaks at the 7.5 and $25 \mathrm{~g} \mathrm{~cm}^{-2}$ depth (Fig. 6). Selected major and trace element concentration profiles show different patterns (Figs. 6 and 7), rather constant for major $\mathrm{Mn}$ and $\mathrm{Fe}$ and trace elements $\mathrm{As}$, $\mathrm{Cr}$ and $\mathrm{Zn}$, and a noticeable increase of $\mathrm{Sb}$ at $1 \mathrm{~g} \mathrm{~cm}^{-2}$ depth with higher variability in the lower layers.

\section{Discussion}

\subsection{Mercury levels}

Sediment $\mathrm{Hg}$ concentrations reaching levels as high as 400 to $650 \mathrm{ng} \mathrm{g}^{-1}$ DW already during pre-industrial accumulation periods as observed in our pristine lakes are far above the background values of 10 to $200 \mathrm{ng} \mathrm{g}^{-1}$ observed in other lakes (Ribeiro Guevara et al., 2005). Also the rates of $\mathrm{Hg}$ accumulation are higher than background levels in the region, from 2 to $8 \mu \mathrm{g} \mathrm{m}^{-2} \mathrm{y}^{-1}$ (Biester et al., 2002; Cooke et al., 2009) or in the North-American Arctic, where preindustrial fluxes range from 1 to $53 \mu \mathrm{g} \mathrm{m}^{-2} \mathrm{y}^{-1}$ and present fluxes from 2 to $114 \mu \mathrm{g} \mathrm{m}^{-2} \mathrm{y}^{-1}$ (Lockhart et al. 1998). In the upper Midwest of the USA Hg fluxes in pre-industrial sediment layers rarely exceed $20 \mu \mathrm{g} \mathrm{m}^{-2} \mathrm{y}^{-1}$, and the maximum fluxes observed here in a pristine area of the southern hemisphere were only exceeded by the highest values in urban areas with industrial pollution (200 to $300 \mu \mathrm{g} \mathrm{m}^{-2} \mathrm{y}^{-1}$, Engstrom and Swain, 1997). Even in a $\mathrm{Hg}$ deposition hotspot area in the USA, recent maximum values reached only $90 \mu \mathrm{g} \mathrm{m}^{-2} \mathrm{y}^{-1}$, after increasing constantly from $7 \mu \mathrm{g} \mathrm{m}^{-2} \mathrm{y}^{-1}$ in 1880 (Hutcheson et al., 2008). Accordingly, the sediment domains with high $\mathrm{Hg}$ accumulation in our lakes during pre-industrial periods (up to $150 \mu \mathrm{g} \mathrm{m}^{-2} \mathrm{y}^{-1}$ ) must be associated to some abrupt phenomena generating $\mathrm{Hg}$ inputs to aquatic environments similar to industrial pollution levels.

For a better evaluation of the watershed and lake surface incidence on the sediments record of atmospheric fallout, Swain et al., 1992 proposed the normalization of $\mathrm{Hg}$ fluxes by the watershed:lake area ratio. The normalized $\mathrm{Hg}$ fluxes are $0.24,2.4$ and $0.72 \mu \mathrm{g} \mathrm{m}^{-2} \mathrm{y}^{-1}$ (background, maximum and recent values, respectively) for Lake Tonček. In the case of Lake Moreno is not clear how to define a watershed affecting the sedimentary sequence analyzed here, because it was extracted from a semi-enclosed bay largely disconnected from the main water course, without hydrodynamical flow studies performed. This normalization, however, requires assumptions to be made, which even if qualitatively supported by a substantial data set may well be inadequate for quantitative corrections particularly for mountain lakes, which such a data set is not available (Meili, 1995).

\subsection{Lakes and mercury}

Several watershed features influence the $\mathrm{Hg}$ concentration in lake sediments. Parameters of catchment morphometry, such as large drainage area, high catchment and lakebed slopes, and large lake depths could be associated to elevated $\mathrm{Hg}$ concentrations in lake sediments (Grigal, 2002; Kainz and Lucotte, 2006). Moreover, dense forest zones in the catchment area are an important source of $\mathrm{Hg}$ to the aquatic systems. Due to the large surface area with canopy foliage, atmospheric deposition of contaminants is elevated in forests 
compared with other ecosystems. The Hg fluxes have contributions due to through fall inputs (precipitation that passes through the canopy) and litter fall (biological material that falls to the forest floor) (Kolka et al., 2001; Porvari et al., 2003; Driscoll et al., 2007). Therefore, according to the general characteristics of the water bodies and catchment areas, higher sediment $\mathrm{Hg}$ concentrations should be expected in Lake Moreno Oeste relative to Lake Tonček, with a smaller drainage area, shallower lake depths and almost absence of vegetation. Particular characteristics of the Lake Tonček watershed have to be considered regarding $\mathrm{Hg}$ concentrations in sediments. An important part of the watershed is covered by wetlands and this kind of lands and their internal processes (high rates of organic matter decomposition, sulphatereducing conditions, potential for methylation) play an important role in the Hg cycle (Goulet et al., 2007; Driscoll et al., 2007; Selvendiran et al., 2008; Larssen et al., 2008). Further, the snow cover for 6 to 8 months per year facilitates the snow-to-air $\mathrm{Hg}$ reemission after photoreduction, which could alter the fate of $\mathrm{Hg}$ after atmospheric deposition when compared with liquid precipitation or fast snow melting, as observed in high altitude/latitude environments (Schroeder et al. 1998; Lalonde et al., 2002; Steffen et al., 2008), although photoreduction also occurs in the water column for all lakes. Also, in warmer periods, the snowmelt and summer storms can represent a significant portion of the annual water and Hg flux from the watershed (Grigal, 2002; Schuster et al., 2008). These features may explain the differences in $\mathrm{Hg}$ sequestration between Lake Tonček and Lake Moreno Oeste, even though a detailed evaluation of the impact exceeds the frame of the present work.

Even though lakes may differ, our sediment data show substantial and apparently synchronous changes over time in both lakes. It is remarkable that the Hg profiles in both sequences show a similar pattern regarding the domains of high pre-industrial $\mathrm{Hg}$, supporting the hypothesis stated previously that external, abrupt phenomena generated substantial $\mathrm{Hg}$ inputs to these aquatic environments. The questions arising afterwards are on the records of environmental changes generated by these phenomena and on the $\mathrm{Hg}$ sources.

\subsection{Environmental factors}

The identification of tephra layers in the sediment sequences is the most concrete evidence of an environmentally disrupting phenomenon, as well as a potential $\mathrm{Hg}$ source: a volcanic eruption. Environmental changes can also be traced at the biological level. Here, the variations in chironomid communities were studied in the Lake Tonček sequence in order to identify population changes that could be associated with environmental events or $\mathrm{Hg}$ inputs although direct heavy metal pollution is recorded better in morphological deformities. Changes in the chironomid assemblages were observed in Lake Tonček sequence, some of them associated with tephra layers. The change of taxa in relative compo- sition allowed the identification of two sections; the oldest accumulation period corresponding to the 11th to 17th centuries with taxa indicating a colder environment, followed by a period with temperate environment (Rizzo et al., 2007). But no correlation was observed between the variation in the chironomid assemblages and the two domains of high $\mathrm{Hg}$. Moreover, the concentration profiles of the other elements as well as OM and BSi contents (Figs. 6 and 7), do not reproduce the $\mathrm{Hg}$ pattern nor do they show any correlation. The absence of correlation of the $\mathrm{Hg}$ concentration with the geochemical tracers studied suggests that no direct geological process in the water body or in the watershed can be associated with the high $\mathrm{Hg}$ values, whereas the lack of correlation with $\mathrm{OM}$ and $\mathrm{BSi}$ is not providing any evidence of biological processes explaining the high $\mathrm{Hg}$ values.

\subsection{Mercury sources}

The other question was on potential $\mathrm{Hg}$ sources that could explain in particular the older domains (1200 to 1350, and 1720 to 1900) of high Hg identified in the Lake Tonček and Lake Moreno Oeste sequences. One potential source is the occurrence of local geothermal emissions (Varenkamp and Buseck, 1986; Nakagawa, 1999). Geothermal activity is usually manifested at the surface as emerging hot waters. Although there are some geothermal systems associated to recent magmatism near this area, they are located along the Andean Range where the active volcanoes are located, about 50 kilometers to the west (Fig. 1). Such indications have not been reported in or near Lake Tonček. There is no volcanic activity in this area that could provide the heat required to generate geothermal activity, and the geothermal energy generated from very deep heat sources is unlikely to reach the altitude of $1750 \mathrm{~m}$ without emerging at any other site of the geological formation. On the other hand, the pattern of the $\mathrm{Hg}$ profile observed in Lake Moreno Oeste is similar, suggesting that concurrent phenomena generated the high $\mathrm{Hg}$ records in both lakes in pre-industrial periods. Geothermal activity was not observed either in or near Lake Moreno. It seems unlikely that geothermal activity can be sufficiently extended to reach Lake Tonček and Lake Moreno Oeste without at the same time producing traces or reports of other geothermal manifestations as superficial thermal waters, occurrence of mineralization in the surrounding landscape, unusual high temperature lake waters, or increasing profiles of other elements in the water column. Therefore, geothermal activity is unlikely a $\mathrm{Hg}$ source to be considered here. Deforestation is another potential source of $\mathrm{Hg}$ to aquatic systems (Porvari et al., 2003). There are no records of massive deforestation before the Spanish colonization in this region, other than by extended forest fires. These were a common deforestation practice both before and after the Spanish colonization (Veblen et al., 2003; Veblen et al., 2003), but may also have occurred naturally together with volcanic events (see below). 
Volcanic events are a well-known source of $\mathrm{Hg}$ on a regional or global scale (Nriagu and Becker, 2003). For example, Schuster et al. (2002) observed in ice cores from the Upper Fremont Glacier, Wyoming, USA, Hg records associated with the eruptions of, among others, volcanoes Tambora (1815) and Krakatau (1883), situated in Indonesia, and determined a contribution of $6 \%$ from remote volcanic events to the $\mathrm{Hg}$ fallout over the last 270 years. Tephra layers are fall ash deposits recording volcanic events that if associated to an increase in $\mathrm{Hg}$ concentration in the deposit or in the upper adjacent layer, give evidence of $\mathrm{Hg}$ releases produced by the volcanic eruption. Tephras TK1 and MO2, which correlate in time and correspond to a possible mixing of products from events at the volcanoes Calbuco and Cordón Caulle (Fig. 1) according to the geochemical characterization (Daga et al., 2008), show a significant increase of $\mathrm{Hg}$ in the overlying layer (Fig. 4), suggesting the occurrence of $\mathrm{Hg}$ gaseous emissions concurrent with the eruption impacting the aquatic systems. Moreover, the micro-tephra in Lake Tonček and tephra MO1 (Fig. 4), corresponding to a volcanic event in 19601961, precede also an increase in the Hg level. Tephra TK6 could be correlated in time with MO5, which shows a noticeable $\mathrm{Hg}$ increase in the overlying layers (Fig. 4). Tephra TK6 corresponds to a mixing layer with products from both Calbuco and Cordón Caulle events, while MO5 corresponds clearly to a Cordón Caulle eruption (Fig. 1). The upper sequence domain with high $\mathrm{Hg}$ concentrations shows tephras, or an overlying layer, with high $\mathrm{Hg}$ concentrations alternating layers with lower values. These $\mathrm{Hg}$ concentrations are the highest determined in the profile. Due to the sharp variations it is not possible to determine an increase over previous levels (Fig. 4), but these high Hg concentrations could be evidence of a volcanic source. In the lower sequence domain with high $\mathrm{Hg}$, tephra layers are concurrent in Lake Moreno Oeste but these volcanic events are not registered in Lake Tonček (Fig. 4). Nevertheless, these high Hg concentrations may be associated to gaseous emissions linked to volcanic events since volcanic ashes can show a highly variable spatial distribution (Daga et al., 2008), because the dynamics of $\mathrm{Hg}$ transport could be different.

Fires are a potential source of atmospheric Hg. Whitlock et al. (2006) studied the incidence of fires in this region during the last 10000 years by measuring charcoal concentrations in a sedimentary sequence extracted from Lake El Trébol, situated near Lake Moreno Oeste (Fig. 1). They computed also the ratio of (grass charcoal)/(total charcoal) which provides information about what component of the vegetation was burning and thus a distinction of surface fires that largely burn grass and herbs, fires that burn both surface cover and woody plants in a patchy manner, and standdestroying crown fires. At Lake El Trébol, charcoal records declined between 3300 to 2000 y before present (BP) and returned to high values between 1500 and $500 \mathrm{y} \mathrm{BP}$. The last $2000 \mathrm{y}$ section of this sequence features variable fire-episode magnitudes, high fire frequency, and short fire-free inter- vals. Two fire episodes of high magnitude were registered in the Lake El Trébol sequence around 800 and 900 y BP. The most recent of them is the highest in charcoal contents registered during the $10000 \mathrm{y} \mathrm{BP}$ period studied by Whitlock et al. (2006). They are associated to a high peak of the ratio of (grass charcoal)/(total charcoal), thus representing the burning of grass and herbs. These high charcoal records are coincident with the lower domain of high $\mathrm{Hg}$ domain observed in Lake Moreno Oeste and Lake Tonček with a date estimated to 1200 to 1350 .

Forest fires release other trace elements to the atmosphere together with $\mathrm{Hg}$ (e.g. As, $\mathrm{Br}, \mathrm{Ca}, \mathrm{Cr}, \mathrm{Fe}, \mathrm{Mg}, \mathrm{Mn}, \mathrm{Se}, \mathrm{Ti}, \mathrm{V}$, or $\mathrm{Zn}$ ) in aerosols or gaseous form, but their imprint in lake sediment sequences depends strongly on the transport dynamics in the atmospheric media, in the watershed and in the water column (Yamasoe et al., 2000; Radojevic, 2003), and no correlation between fires and trace element contents in lake sediment sequences was observed in some cases (MacDonald et al., 1991; Virkanen, 2000). Moreover, high Hg enrichment in air above background concurrent with no significant variation in any other trace elements, was observed associated with forest fires (Anttila et al., 2008). Therefore, the lack of correlation between $\mathrm{Hg}$ and the other trace elements analyzed in the present work does not preclude forest fires as a potential $\mathrm{Hg}$ source.

Extended forest fires associated with human activities occurred indeed during the 18th and 19th centuries. Native Americans affected fire regimes and the landscapes of Northern Patagonia through intentional burning for various purposes, which occasionally might have lead to wildfires (Veblen et al., 2003). European settlement, starting in the region about 1850 but earlier in Chile (since the end of the 17th century), was associated with large fires for forest clearance, intensive livestock grazing, and opening of paths across the Andes through the forest (Veblen et al., 1992). From 1890 to 1920 extensive areas of wet forests were burned in the study region by European settlers, in a failed effort to convert forests to cattle pasture (Kitzberger et al. 1997). Particularly, direct observation of large burns was reported in 1787 in the Lake Nahuel Huapi region, towards the lake South-West (Veblen et al., 2003). By analyzing tree-ring data, Kitzberger et al. (1997) determined the occurrence of an extended fire in Lake Roca (Fig. 1) in 1827. These fires may well have had an impact directly on the Lake Tonček watershed due to the predominantly westerly winds, reaching possibly also Lake Moreno Oeste watershed (Fig. 1). These events coincide with the upper domain of high $\mathrm{Hg}$ at Lake Tonček and Lake Moreno Oeste sedimentary sequences. In both periods, the fire records are concurrent with ENSO (El Niño-Southern Oscillation) events which may enhance environmental conditions favouring extended fires.

In conclusion, the correlation of both high $\mathrm{Hg}$ domains in the Lake Moreno Oeste and Lake Tonček sequences with records of extended fires in the region suggests that this source, as well as the volcanic activity, could have generated 
the high levels and variations of $\mathrm{Hg}$ concentrations and accumulation rates observed in these pristine lakes already in pre-industrial times.

Acknowledgements. Pia Kärrhage is gratefully acknowledged for technical assistance with the $\mathrm{Hg}$ analyses, and also Ricardo Sánchez for the collaboration in sediment sampling. This work was funded by project PICT 13-13276, Agencia Nacional de Promoción Científica y Tecnológica, Argentina.

Edited by: R. Ebinghaus

\section{References}

Amirbahman, A., Ruck, P. L., Fernández, I. J., Haine, T. A., and Kahl, J. A.: The effect of fire on mercury cycling in the soils of forested watersheds Acadia National Park, Maine, USA, Water Air Soil Pollut., 152, 313-331, 2004.

Anttila, P., Makkonen, U., Hellén, H., Kyllönen, K., Leppänen, S., Saari, H., and Hakola, H.: Impact of the open biomass fires in spring and summer of 2006 on the chemical composition of background air in south-eastern Finland, Atmos. Environ., 42, 64726486, 2008.

Arribére, M., Ribeiro Guevara, S., Bubach, D., Arcagni, M., and Vigliano, P.: Selenium and Mercury in Native and Introduced Fish Species of Patagonian Lakes, Argentina, Biol. Trace Elem. Res., 122, 42-63, 2008.

Biester, H., Kilian, R., Frazen, C., Woda, C., Magnini, A., and Sholer, H. F.: Elevated mercury accumulation in a peat bog of the Magellanic Moorlands, Chile $\left(53^{\circ} \mathrm{S}\right)$ - an anthropogenic signal from the Southern Hemisphere. Earth Planet. Sci. Lett., 201, 609-620, 2002.

Biester, H., Bindler, R., Martínez-Cortizas, A., and Engstrom, D.: Modeling the past atmospheric deposition of mercury using natural archives, Environ. Sci. Technol., 41, 4851-4860, 2007.

Caldwell, C. A., Canavan, C. M., and Bloom, C. M.: Potential effects of forest fire and storm flow on total mercury and methylmercury in sediments of an arid-lands reservoir, Sci. Total Environ., 260, 125-133, 2000.

Cooke, C. A., Balcom, P. H., Biester, H., and Wolfe, A. P.: Over three millennia of mercury pollution in the Peruvian Andes, PNAS, 106, 8830-8834, 2009.

Daga, R., Ribeiro Guevara, S., Sánchez, M. L., and Arribére, M.: Source identification of volcanic ashes by geochemical analysis of well preserved lacustrine tephras in Nahuel Huapi National Park, Appl. Radiat. Isotopes, 66, 1325-1336, 2008.

DeMaster, D. J.: The supply and accumulation of silica in the marine environment, Geochim. Cosmochim. Ac., 45, 1715-1732, 1981.

Díaz, M., Pedrozo, F., Reynolds, C., and Temporetti, P.: Chemical composition and the nitrogen-regulated trophic state of Patagonian lakes, Limnologica, 37, 17-27, 2007.

Downs, S. G., Macleod, C. L., and Lester, J. N.: Mercury in precipitation and its relation to bioaccumulation in fish: a literature review. Water Air Soil Pollut., 108, 149-187, 1998.

Driscoll, C., Han, Y., Chen, C., Evers, D., Lambert, K., Holsen, T., Kamman, N., and Munso, R.: Mercury contamination in forest and freshwater ecosystems in the northeastern United States, BioScience, 57, 17-28, 2007.
Engstrom, D. and Swain, E.: Recent decline in atmospheric mercury deposition in the UpperMidwest, Environ. Sci. Technol., 31, 960-967, 1997.

Ferrara, R., Mazzolai, B., Lanzillotta, E., Nucaro, E., and Pirrone, N.: Volcanoes as emission sources of atmospheric mercury in the Mediterranean basin, Sci. Total Environ., 259, 115-121, 2000.

Friedli, H. R., Radke, L. F., Lu, J. Y., Banic, C. M., Leaitch, W. R., and MacPherson, J. I.: Mercury emissions from burning of biomass from temperate North American forests: laboratory and airborne measurements, Atmos. Environ., 37, 253-267, 2003.

Goulet, R., Holmes, J., Page, B., Poissant, L., Siciliano, S., Lean, D., Wang., F., Amyot, M., and Tessier, A.: Mercury transformations and fluxes in sediments of a riverine wetland, Geochim. Cosmochim. Ac., 71, 3393-3406, 2007.

Grigal, D.: Inputs and outputs of mercury from terrestrial watersheds: a review, Environ. Rev., 10, 1-39, 2002.

Harden, J. W., Neff, J. C., Sandberg, D. V., Turetsky, M. R., Ottmar, R., Gleixner, G., Fries, T. L., and Manies, K. L.: Chemistry of burning the forest floor during the FROSTFIRE experimental burn, interior Alaska, Global Biogeochem. Cy. 18, GB3014, doi:10.1029/2003GB002194, 2004.

Hutcheson, M. S., Smith, S. M., Wallace, G. T., Rose, J., Eddy, T., Sullivan, J., Pancorbo, O., and Rowan West, C.: Freshwater Fish Mercury Concentrations in a Regionally High Mercury Deposition Area, Water Air Soil Pollut., 191, 15-31, 2008.

Joshi. S. R. and Shukla, B. S.: AB initio derivation of formulations for ${ }^{210} \mathrm{~Pb}$ dating of sediments, J. Radioanal. Nucl. Chem., 148, 73-79, 1991.

Kainz, M. and Lucotte, M.: Mercury concentrations in lake sediments - Revisting the predictive power of catchment morphometry and organic matter composition, Water Air Soil Pollut., 170, 173-189, 2006.

Kitzberber, T., Veblen, O., and Villalba, R.: Climatic influences on fire regimes along a rain forest-to-xeric woodland gradient in northern Patagonia, Argentina, J. Biogeogr., 24, 35-47, 1997.

Kolka, R., Grigal, D., Nater, E., and Verry, E.: Hydrologic Cycling of mercury and organic carbon in a forested upland-bog watershed, Soil Sci. Soc. Am. J., 65, 897-905, 2001.

Lalonde, J. D., Poulain, A. J. and Amyot, M.: The role of mercury redox reactions in snow on snow-to-air mercury transfer, Environ. Sci. Technol., 36, 174-178, 2002.

Lamborg, C. H., Fitzgerald, W. F., Damman, A. W. H., Benoit, J. M., Balcom, P. H., and Engstrom, D. R.: Modern and historic atmospheric mercury fluxes in both hemispheres: Global and regional mercury cycling implications. Global Biogeochem. Cy., 16(4), 1104, doi:10.1029/2001GB001847, 2002.

Langway, C., Osada, K., Clausen, H., Hammer, C., and Shoji, H.: A 10-century comparison of prominent bipolar volcanic events in ice cores, J. Geophys. Res., 100, 16241-16247, 1995.

Larssen, T., Wit, H., Wiker, M., and Halse, K.: Mercury budget of a small forested boreal catchment in southeast Norway, Sci. Total Environ., 404, 290-296, 2008.

Lindqvist, O., Johansson, K., Aastrup, A., Anderson, A., Bringmark, L., Hovsenius, G., Iverfeldt, A., Meili, M., and Timm, B.: Mercury in the Swedish environment - Recent research on causes, consequences and corrective methods, Water Air Soil Pollut. 55, 1-261, 1991.

Lockhart, W. L., Wilkinson, P., Billeck, B. N., Danell, R. A., Hunt, R. V., Brunskill, G. J., Delaronde, J., and St. Louis, V.: Fluxes 
of mercury to lake sediments in central and northern Canada inferred from dated sediment cores, Biogeochemistry, 40, 163173, 1998.

MacDonald, G. M., Larsen, C. P. S., Szeicz, J. M., and Moser, K. A.: The reconstruction of boreal forest fire history from lake sediments: a comparison of charcoal, pollen, sedimentological and geochemical indices, Quaternary Sci. Rev., 10, 53-71, 1991.

Marinone, M.C., Menu Marque, S., Añón Suárez, D., Diéguez, M.C., Pérez, P., De Los Ríos, P., Soto, D., and Zagarese, H.E.: UV Radiation as a potential driving force for zooplankton community structure in Patagonian lakes. Photochem. Photobiol., 82, 962-971, 2006.

Meili, M.: Pre-industrial atmospheric deposition of mercury: uncertain rates from lake sediment and peat cores. Water Air Soil Pollut., 80, 637-640, DOI:10.1007/BF01189716, 1995.

Morris, D., Zagarese, C., Williamson, C., Balseiro, E., Hargreaves, B., Modenutti, R., Moeller, R., and Queimaliños, C.: The attenuation of solar UV radiation in lakes and the roles of dissolved organic carbon, Limnol. Oceanogr., 40, 1381-1391, 1995.

Nakagawa, R.: Estimation of mercury emissions from geothermal activity in Japan, Chemosphere, 38, 1867-1871, 1999.

Nriagu, J.: A global assessment of natural sources of atmospheric trace metals, Nature, 338, 47-49, 1989.

Nriagu, J. and Becker, C.: Volcanic emissions of mercury to the atmosphere: global and regional inventories, Sci. Total Environ., 304, 3-12, 2003.

Porvari, P., Verta, M., Munthe, J., and Haapanen, M.: Forestry practices increase mercury and methyl mercury output from boreal forest catchments, Environ. Sci. Technol., 37, 2389-2393, 2003.

Queimaliños, C. P., Modenutti, B. E., and Balseiro, G. E.: Symbiotic association of the ciliate Ophrydium naumanni with Chlorella causing a deep chlorophyll $\alpha$ maximum in an oligotrophic South Andes lake, J. Plankton Res., 21, 167-178, 1999.

Radojevic, M.: Chemistry of forest fires and regional haze with emphasis on southeast Asia, Pure Appl. Geophys., 160, 157-187, 2003.

Ramos, V.: Rasgos estructurales del Territorio Argentino, Geología Argentina, SEGEMAR, Buenos Aires, 715-759, 1999.

Rasmussen, P.: Current methods of estimating atmospheric mercury fluxes in remote areas, Environ. Sci. Technol., 28, 2233-2241, 1994.

Ribeiro Guevara, S. and Arribére, M.: ${ }^{137}$ Cs dating of sedimentary cores from lakes of Nahuel Huapi National Park, Patagonia, Argentina: historical records and profile measurements, J. Radioanal. Nucl. Ch., 252, 37-45, 2002.

Ribeiro Guevara, S., Rizzo, A., Sánchez, R., and Arribére, M.: ${ }^{210} \mathrm{~Pb}$ fluxes in sediment layers sampled from Northern Patagonia lakes, J. Radioanal. Nucl. Ch., 258, 583-595, 2003.

Ribeiro Guevara, S., Bubach, D., and Arribére, M.: Mercury in Lichens of Nahuel Huapi National Park, Patagonia, Argentina, J. Radioanal. Nucl. Ch., 261, 679-687, 2004a.

Ribeiro Guevara, S., Bubach, D., Vigliano, P. H., Lippolt, G., and Arribére, M.: Heavy metals and other trace elements in native mussel Diplodon chilensis from Northern Patagonia lakes, Argentina, Biol. Trace Elem. Res., 102, 245-264, 2004 b.

Ribeiro Guevara, S., Rizzo, A., Sánchez, R., and Arribére, M.: Heavy metal inputs in Northern Patagonia lakes from short sediment cores analysis, J. Radioanal. Nucl. Ch., 265, 481-493, 2005.
Rizzo, A., Ribeiro Guevara, S., Arribére, M., and Massaferro, J.: Study of subfossil chironomid assemblages of the last $900 \mathrm{yr}$ recorded in a sediment sequence from a high altitude lake of Northern Patagonia (Argentina), Proceedings of the 4th International Limnogeology Congress, 11-14 July, Barcelona, Spain, 2007.

Robbins, J. A. and Herche, L. R.: Models and uncertainty in ${ }^{210} \mathrm{~Pb}$ dating of sediments, Verh. Internat. Verein. Limnol., 25, 217222, 1993.

Schroeder, W. and Munthe, J.: Atmospheric mercury - an overview, Atmos. Environ., 32, 809-822, 1998.

Schroeder, W., Anlauf, K., Barrie, L., Steffen, A., Lu, J., and Schneeberger, D.: Arctic springtime depletion of mercury, Nature, 394, 331-332, 1998.

Schuster, P. F., Krabbenhoft, D. P., Naftz, D. L., Cecil, L. D., Olson, M. L., Dewild, J. F., Susong, D. D., Green, J. R., and Abbott, M. L.: Atmospheric mercury deposition during the last 270 years: a glacial ice core record of natural and anthropogenic sources, Environ. Sci. Technol., 36, 2303-2310, 2002.

Schuster, P., Shanley, J., Marvin-Dipasquale, M., Reddy, M., Aiken, G., Roth, D., Taylor, H, Kraggenhoft, D., and DeWild, J.: Mercury and organic carbon dynamics during runoff episodes from a Northeastern USA watershed, Water Air Soil Pollut., 187, 89108, 2008.

Selvendiran, P., Driscoll, C., Bushey, J., and Montesdeoca, M.: Wetland influence on mercury fate and transport in a temperate forested watershed, Environ. Pollut., 154, 46-55, 2008.

Siegel, S. and Siegel, B.: Geothermal hazards. Mercury emission, Environ. Sci. Technol., 9, 473-474, 1975.

Sigler, J. M., Lee, X., and Munger, W.: Emission and long-range transport of gaseous mercury from a large-scale Canadian boreal forest fire, Environ. Sci. Technol., 37, 4343-4347, 2003.

Steffen, A., Douglas, T., Amyot, M., Ariya, P., Aspmo, K., Berg, T., Bottenheim, J., Brooks, S., Cobbett, F., Dastoor, A., Dommergue, A., Ebinghaus, R., Ferrari, C., Gardfeldt, K., Goodsite, M. E., Lean, D., Poulain, A. J., Scherz, C., Skov, H., Sommar, J., and Temme, C.: A synthesis of atmospheric mercury depletion event chemistry in the atmosphere and snow, Atmos. Chem. Phys., 8, 1445-1482, 2008,

http://www.atmos-chem-phys.net/8/1445/2008/.

Stern, C.: Active Andean volcanism: its geologic and tectonic setting, Revista Geológica de Chile, 31, 161-206, 2004.

Swain, E. B., Engstrom, D. R., Brigham, M. E., Henning T. A., and Brezonik, P. L.: Increasing rates of atmospheric mercury deposition in midcontinental North America, Science, 257, 784-787, 1992.

Tomiyasu, T., Nagano, A., Sakamoto, H., and Yonehara, N.: Background levels of atmospheric mercury in Kagoshima City, and influence of mercury emission from Sakurajima Volcano, southwestern Kyushu, Japan, Sci. Total Environ., 259, 231-237, 2000.

US-EPA: Mercury in solids and solutions by thermal decomposition, amalgamation, and atomic absorption spectrophotometry. EPA Method 7473 (SW-846), United States Environmental Protection Agency, Washington DC, USA, available online at: http://www.epa.gov/sw-846/pdfs/7473.pdf, 2007.

Varenkamp, J. and Busek, P.: Changing mercury anomalies in Long Valley, Califormia: indication for magma movement or seismic activity, Geology, 12, 283-286, 1984.

Varenkamp, J. and Busek, P.: Global Hg flux from volcanic and 
geothermal sources, Appl. Geochem., 1, 65-73, 1986.

Veblen, T. T., Kitzberger, T., Raffaele, E., and Lorenz, D. C.: Fire history and vegetation changes in northern Patagonia, Argentina, in: Fire and Climatic Change in Temperate Ecosystems of the Western Americas, edited by: Veblen, T. T., Baker, W. L., Montenegro, G., Swetnam, W. T., Springer, New York, USA, 259289, 2003.

Veblen, T. T., Kitzberger, T., and Lara, A.: Disturbance and forest dynamics along a transect from Andean rain forest to Patagonian shrubland, J. Veg. Sci., 3, 507-520, 1992.

Virkanen, J.: The effects of natural environmental changes on sedimentation in Lake Kuttanen, a small closed lake in Finnish Lapland, The Holocene 10, 377-386, 2000.

Walker, I. R.: Midges: Chironomidae and related Diptera, in: Tracking environmental changes using lakes sediments, edited by: Smol, J. P., Birks, H. J. B., Last, W. M., Volume 4: Zoological indicators, Kluwer Academic Publishers, Dordrecht, The Netherlands, 43-66, 2001.
Weissberg, B. and Rohde, A.: Mercury in some New Zealand geothermal discharges, N. Z. J. Sci., 21, 365-369, 1978.

Wiedinmyer, C. and Friedly, H.: Mercury emission estimates from rires: an initial inventory for the United States, Environ. Sci. Technol., 41, 8092-8098, 2007.

Whitlock, C., Bianchi, M. M., Bartlein, P.J., Markgraf, V., Marlon, J., Walsh, M., and McCoy, N.: Postglacial vegetation, climate, and fire history along the east side of the Andes (lat $41-42.5^{\circ} \mathrm{S}$ ), Argentina. Quaternary Res. 66, 187-201, 2006.

Yamasoe, M. A., Artaxo, P., Miguel, A. H., and Allen A. G.: Chemical composition of aerosol particles from direct emissions of vegetation fires in the Amazon Basin: water-soluble species and trace elements, Atmos. Environ. 34, 1641-1653, 2000. 